OPEN ACCESS

Edited by:

Peter Mullany,

University College London, UK

Reviewed by:

Eric Christopher Keen,

Washington University, USA

Benjamin Andrew Evans,

Anglia Ruskin University, UK

D. Ipek Kurtboke,

University of the Sunshine Coast,

Australia

*Correspondence:

Jean-Yves Maillard

maillardj@cardiff.ac.uk

${ }^{\dagger}$ Deceased

Specialty section:

This article was submitted to Antimicrobials, Resistance

and Chemotherapy,

a section of the journa

Frontiers in Microbiology

Received: 06 June 2016

Accepted: 19 July 2016

Published: 03 August 2016

Citation:

Henein AE, Hanlon GW, Cooper CJ, Denyer SP and Maillard J-Y (2016)

A Partially Purified Acinetobacter baumannii Phage Preparation Exhibits no Cytotoxicity in 3T3 Mouse

Fibroblast Cells.

Front. Microbiol. 7:1198.

doi: 10.3389/fmicb.2016.01198

\section{A Partially Purified Acinetobacter baumannii Phage Preparation Exhibits no Cytotoxicity in 3T3 Mouse Fibroblast Cells}

\author{
Alexandra E. Henein ${ }^{1+}$, Geoffrey W. Hanlon ${ }^{1}$, Callum J. Cooper ${ }^{2}$, Stephen P. Denyer ${ }^{1}$ and \\ Jean-Yves Maillard ${ }^{3 *}$ \\ ${ }^{1}$ School of Pharmacy and Biomolecular Sciences, Brighton University, Brighton, UK, ${ }^{2}$ Department of Molecular Biosciences, \\ The Wenner-Gren Institute, Stockholm University, Stockholm, Sweden, ${ }^{3}$ Cardiff School of Pharmacy and Pharmaceutical \\ Sciences, Cardiff University, Cardiff, UK
}

A surge in the level and scale of antibiotic resistance has prompted renewed interest in the application of bacteriophages to treat bacterial infections. However, concerns still exist over their efficacy and safety. Acinetobacter baumannii phage BS46, a member of the family Myoviridae, has previously been shown to be effective in murine models. The cytotoxic effect of this phage was evaluated in mouse fibroblast 3T3 cells using four different assays: trypan blue; staining with Hoechst and propidium iodide; lactate dehydrogenase release; and the MTS assay. The addition of phage concentrations up to $2 \times 10^{9} \mathrm{pfu} / \mathrm{mL}$ showed little to no impact on the viability of 3T3 cells after $24 \mathrm{~h}$ exposure using the different assays. This study demonstrates that phage BS46 is noncytotoxic to 3T3 cells using four different assays and that appropriate quality assurance protocols for phage therapeutics are required.

Keywords: bacteriophage, cytotoxicity, Acinetobacter baumannii, lactate dehydrogenase, MTS assay, trypan blue, hoechst stain, propidium iodide

\section{INTRODUCTION}

There is a resurgence of interest in phage to treat multidrug resistant infections in humans, with some bacteriophage (phage) products entering clinical trials (Rhoads et al., 2009; Wright et al., 2009) or in animal testing (Biswas et al., 2002; Morello et al., 2011). Although the use of phages within a clinical setting dates back to the early part of the 20th Century (Kutter et al., 2010), their use has been primarily confined to the former Soviet Union and Eastern Europe, in part due to concerns about safety and efficacy (Hanlon, 2007). Small numbers of phage preparations have been approved by the U.S. Food \& Drug Administration for use as food additives within the food industry for the control of Listeria monocytogenes (Bren, 2007) and within the European Union (Anonymous, 2012). The small amount of human clinical trial data that exists in currently available literature has not demonstrated toxicity issues (Merabishvili et al., 2009). However, the potential to induce an immune response regardless of the level of preparation purity is of major concern to those seeking to utilize phage therapy clinically. There are a number of assays available to measure cell cytotoxicity. These often differ in the parameters they measure and have been shown to exhibit different levels of sensitivity (Fotakis and Timbrell, 2006). No standard assay for determining the cytotoxic effect of phage has been reported. 
Acinetobacter baumannii is an opportunistic human pathogen causing a wide range of infections including wound, urinary tract infections (Antunes et al., 2014) and ventilator-acquired pneumonia (Qureshi et al., 2015). A. baumannii is an important multidrug resistant microorganism (Cai et al., 2012; Zarrilli et al., 2013; Antunes et al., 2014), with resistance to colistin being recently reported (Qureshi et al., 2015). The use of phages against this important pathogen is an exciting prospect, but for application in humans, particularly for wound infections, their cytotoxicity needs to be evaluated. Here the A. baumannii phage BS46, a member of the Myoviridae family was used. It has previously been shown to provide a protective effect in mice when challenged with up to five times the $\operatorname{LD}_{50}\left(10^{8} \mathrm{cfu}\right)$ of A. baumannii (Soothill, 1992).

The current investigation sought to determine the cytotoxic effects of a single A. baumannii phage and to evaluate different methods of determining cytotoxic effect following the addition of bacteriophage.

\section{MATERIALS AND METHODS}

All chemicals and reagents were obtained from Fisher Scientific (Loughborough, UK) or Sigma-Aldrich (Gillingham, UK) unless otherwise stated in the text.

Sterile Lambda $(\lambda)$ buffer was prepared by the addition of $2.5 \mathrm{~mL} 2 \%(\mathrm{w} / \mathrm{v})$ gelatin to $6 \mathrm{~mL} 1 \mathrm{M}$ Tris base at $\mathrm{pH} 7.2$. To this $2.5 \mathrm{~g} \mathrm{MgSO}_{4} .7 \mathrm{H}_{2} \mathrm{O}$ was added and the resulting suspension made up to $1 \mathrm{~L}$ with $\mathrm{dH}_{2} \mathrm{O}$. The resulting solution was then autoclaved at $121^{\circ} \mathrm{C}$ for $15 \mathrm{~min}$.

\section{Routine Culture of Bacterial and Bacteriophage Strains}

Acinetobacter baumannii HER1401 and phage BS46 (Soothill, 1992; Ackermann et al., 1994) were obtained from The Felix d'Hérelle Reference Center for Bacterial Viruses, GREB, Faculté de Médecine Dentaire, Université Laval, Canada.

Acinetobacter baumannii HER1401 cultured in Tryptone Soy Broth (TSB; Oxoid, Basingstoke, UK) for $18 \mathrm{~h}$ at $37^{\circ} \mathrm{C}$ under $120 \mathrm{rpm}$ agitation was used to inoculate $100 \mathrm{~mL}$ TSB. That was then incubated for $3-5 \mathrm{~h}$ at $37^{\circ} \mathrm{C}$ under $120 \mathrm{rpm}$ agitation until an $\mathrm{OD}_{600}$ of $0.5\left(\sim 10^{8} \mathrm{cfu} / \mathrm{mL}\right)$ was reached. Bacterial suspensions were then infected with $1 \mathrm{~mL}$ phage suspension $\left(\sim 10^{6} \mathrm{pfu} / \mathrm{mL}\right)$, statically incubated at $37^{\circ} \mathrm{C}$ for $15 \mathrm{~min}$ and then incubated for a further $18 \mathrm{~h}$ at $37^{\circ} \mathrm{C}$ and $120 \mathrm{rpm}$.

Following incubation $10 \mathrm{~mL}$ chloroform was added and then the suspensions were incubated at $37^{\circ} \mathrm{C}, 120 \mathrm{rpm}$ for $10 \mathrm{~min}$ prior to centrifugation at $2500 \times g$ for $10 \mathrm{~min}$. The resulting supernatant was then passed through a $0.45 \mu \mathrm{m}$ syringe filter (Millipore, UK) to produce a crude lysate.

\section{Production of Concentrated Purified Phage}

Prior to use, crude lysates were enumerated and assessed for viability using the agar overlay method (Adams, 1959). To each crude lysate, sodium chloride was added to give a $1 \mathrm{M}$ final concentration, stored on ice for $1 \mathrm{~h}$ and centrifuged at
$11000 \times g$ for $10 \mathrm{~min}$ at $4^{\circ} \mathrm{C}$. Following centrifugation, $10 \%$ $(\mathrm{w} / \mathrm{v})$ polyethylene glycol 8000 (PEG 8000) was added to the supernatant and stored at $4^{\circ} \mathrm{C}$ for $18 \mathrm{~h}$.

Suspensions were centrifuged at $11000 \times g$ for $10 \mathrm{~min}$ at $4^{\circ} \mathrm{C}$, the supernatant discarded, the pellet re-suspended in $11 \mathrm{~mL} \lambda$ buffer and $1 \mathrm{~mL}$ chloroform. The organic and aqueous phases were separated by centrifugation at $3000 \times g$ for $15 \mathrm{~min}$ at $4^{\circ} \mathrm{C}$. The organic phase was discarded and the aqueous phase made up to $50 \mathrm{~mL}$ with $\lambda$ buffer and passed twice through $0.45 \mu \mathrm{m}$ filters. Purified phage preparations were diluted in $\lambda$ buffer to provide a working suspension of $8 \times 10^{9} \mathrm{pfu} / \mathrm{mL}$ and enumerated using the agar overlay method as previously described (Adams, 1959) and stored in sterile glass containers at $2-8^{\circ} \mathrm{C}$.

Prior to use in cytotoxicity experiments, phages were diluted in $\lambda$ buffer to yield $2 \times 10^{9}, 2 \times 10^{8}$, and $2 \times 10^{7} \mathrm{pfu} / \mathrm{mL}$ and suspensions equilibrated to room temperature.

\section{Cell Culture}

Acinetobacter baumannii is a known bacterial pathogen associated with wounds. The embryonic Swiss albino mouse fibroblast cell line ' 3 T3(+3)' ECACC No. 89022402 was used here as a model since fibroblasts are associated with wound healing. 3T3 cells were grown in Dulbecco's Modified Eagle's Medium (DMEM) supplemented with $1 \mathrm{~g} / \mathrm{L}$ glucose, L-glutamine and sodium bicarbonate, $10 \%(\mathrm{v} / \mathrm{v})$ fetal calf serum (FCS) and $1 \%(\mathrm{v} / \mathrm{v})$ penicillin and streptomycin. All cells were incubated at $37^{\circ} \mathrm{C}$ with $5 \% \mathrm{CO}_{2}$ in a humidified atmosphere.

\section{Analysis of Bacteriophage Cytotoxicity in 3T3 Cells \\ Preparation of Cells for Use in Cytotoxicity Experiments}

Working culture plates were produced by the addition of 5000 , 10000,15000 , or $2 \times 10^{5} 3 \mathrm{~T} 3$ cells (depending on the assay type) to wells of sterile Nunclon surface 24-well cell culture plates (Nunc Denmark) into a total volume of $1 \mathrm{~mL}$ pre-warmed supplemented DMEM and incubated for $24 \mathrm{~h}$ at $37^{\circ} \mathrm{C}$ in $95 \%$ air: $5 \% \mathrm{CO}_{2}$ in a humidified atmosphere.

In order to remove mouse fibroblast 3T3 cells from 24 well plates, DMEM was removed, $200 \mu \mathrm{L}$ of trypsin added to each well and plates incubated for $3-5 \mathrm{~min}$ at $37^{\circ} \mathrm{C}$ in a $95 \%$ air: $5 \%$ $\mathrm{CO}_{2}$ atmosphere. Cell suspensions were centrifuged at $400 \times g$ for $5 \mathrm{~min}$, the supernatant discarded and the pellet re-suspended in $1 \mathrm{~mL}$ fresh DMEM.

\section{Trypan Blue Exclusion Assay}

$3 \mathrm{~T} 3$ cell suspensions and $50 \mu \mathrm{L}$ purified phage in experimental wells $(n=6)$ were prepared and incubated for 24,48 , and $72 \mathrm{~h}$ as before. $\lambda$ buffer was used as a negative control.

Following trypsinisation, cell viability was assessed using a Trypan blue assay (Strober, 2001). In brief, $20 \mu \mathrm{L}$ of cell suspension was added to $4 \mu \mathrm{L} 0.4 \%$ (w/v) trypan blue solution in phosphate buffered saline (Sigma-Aldrich, Gillingham, UK) and the total number of cells immediately quantified from five squares of a haemocytometer at $100 \times$ magnification using an inverted light microscope (Wilovert standard; Hund Wetzlar, Germany). 
If the cell density was too high then cells were diluted 1:10 in DMEM prior to imaging. Unstained cells were considered to be alive while blue stained cells were considered to be dead. In all cases, samples from each well were read in quintuplicate on two different occasions.

\section{Hoechst and Propidium lodide Staining for Cell Apoptosis}

BS46 phages were inoculated to growing $3 \mathrm{~T} 3$ cells as described above. $\lambda$ buffer was used as a negative control.

Viable and apoptotic cells were quantified at multiple time points $(t=24,48,72 \mathrm{~h}$ ) after phage addition using a modified propidium iodide (PI) staining method (Belloc et al., 1994). In brief, $900 \mu \mathrm{L}$ of DMEM was mixed with $50 \mu \mathrm{L}$ of a $1 \mathrm{mg} / \mathrm{mL}$ (in $10 \mathrm{~mL}$ demineralized water) PI solution and $50 \mu \mathrm{L}$ of bisbenzimide. Wells were stained with PI and six random fields of view counted using an Axiovert 25 inverted fluorescence microscope (Karl Zeiss Ltd., Welwyn Garden City, UK) with a $420 \mathrm{~nm}$ filter. Viable cells were identified by uniform blue fluorescence and apoptotic cells by their fragmented nuclei with either blue or pink fluorescence.

\section{Lactate Dehydrogenase (LDH) Release}

Lactate Dehydrogenase (LDH) values were determined using the CytoTox 96 Non-Radioactive cytotoxicity assay (Promega, Southampton, UK) according to the manufacturer's instructions. Absorbance at $492 \mathrm{~nm}$ was determined in an automatic Titertek Multiskan Plus MKII plate reader (LabX, Midland, ON, Canada), at $492 \mathrm{~nm}$. Absorbance values were adjusted to compensate for the contribution of DMEM and the percentage cytotoxicity calculated as below;

$\%$ Cytotoxicity $=[$ Experimental LDH release/Maximum LDH release] $\times 100$.

\section{Cell Viability Using an MTS Assay}

Fifty micro liter of purified phage suspension were added to the experimental wells and incubated for 24,48 , and $72 \mathrm{~h}$ as described above. Negative controls containing $50 \mu \mathrm{L} \lambda$ buffer and untreated cells were also performed. The number of viable cells was determined using the CellTiter 96 aqueous One Solution Cell Proliferation Assay (MTS; Promega, Madison, WI, USA) according to the manufacturer's instructions. Absorbance at $492 \mathrm{~nm}$ was determined on an automatic Titertek Multiskan Plus MKII plate reader (LabX, Midland, Canada) and expressed as a percentage of non-treated controls to calculate the percentage proliferation status (Carmichael et al., 1987).

\section{Statistical Analysis}

All experiments were performed in triplicate on different days unless otherwise stated in the text.

\section{Trypan Blue Exclusion Test}

Data were statistically analyzed using a Kruskal-Wallis One way analysis of variance due to the data being non-normally distributed.

\section{Apoptotic Assay}

Data were statistically treated using a Univariate General linear model and Levene's test.

\section{MTS Assay}

One-way between groups ANOVA with Tukey's post hoc test was used to compare cell viability as percentage of controls.

\section{RESULTS}

\section{Trypan Blue Assay}

The initial concentration of phage showed a non-significant impact $(p>0.05)$ on the viability of 3T3 cells after 24 h exposure (Figure 1) with $2 \times 10^{8} \mathrm{pfu} / \mathrm{mL}$ exhibiting the highest reduction in viability $(\sim 10 \%)$. Seeding density $\left(5 \times 10^{3}\right.$ or $2 \times 10^{5}$ cells/well) also had no significant effect on the viability of cells following $24 \mathrm{~h}$ exposure to phage ( $p>0.1$ Tukey's and KruskalWallis).

\section{Hoechst and Propidium lodide Staining}

Statistically significant reductions in the number of viable cells were observed following $72 \mathrm{~h}$ incubation with either $2 \times 10^{7}$ and $2 \times 10^{8} \mathrm{pfu} / \mathrm{mL}$ compared to untreated controls (Figure 2; $p<0.001)$. Incubation time had no significant impact on cell viability $(p=0.418)$.

\section{LDH Release}

Phage addition at varying concentrations resulted in small but not statistically significant increases in cell death compared to untreated samples (between 5 and $10 \%$ reduction; Figure 3 ) with the exception of $2 \times 10^{9} \mathrm{pfu} / \mathrm{mL}$ at $24 \mathrm{~h}(p<0.001)$.

\section{MTS Assay}

Following $24 \mathrm{~h}$ exposure to different concentrations of phages $\left(2 \times 10^{9}, 2 \times 10^{8}\right.$, or $\left.2 \times 10^{7} \mathrm{pfu} / \mathrm{mL}\right)$ the number of viable cells appeared to increase at higher initial seeding densities (10000 and 15000 cells/well) compared to controls treated with $\lambda$ buffer only (Figure 4A). At $48 \mathrm{~h}$ incubation there was no significant difference between phage samples and $\lambda$ buffer (Figure 4B; $p>0.5$ ). After $72 \mathrm{~h}$ cells exposed to phages cell viability increased significantly compared to the controls. Cells seeded at 10000 cells/well remained more viable (Figure 4C; $p<0.05$ ) when exposed to $2 \times 10^{9}$ and $2 \times 10^{8} \mathrm{pfu} / \mathrm{mL}$ phage, compared to $\lambda$ buffer and untreated (DMEM only) cells.

\section{DISCUSSION}

Bacterial cell products can have both direct and indirect cytotoxic effects on cells in the stationary phase (Perfetto et al., 2003), particularly through the action of bacterial endotoxins which affect the expression of adhesion molecules, inflammatory responses (Tang et al., 2011), cytokine release (Perfetto et al., 2003; Tardif et al., 2004), or the release of bacterial toxins (Los et al., 2013). However, little information exists in the current 


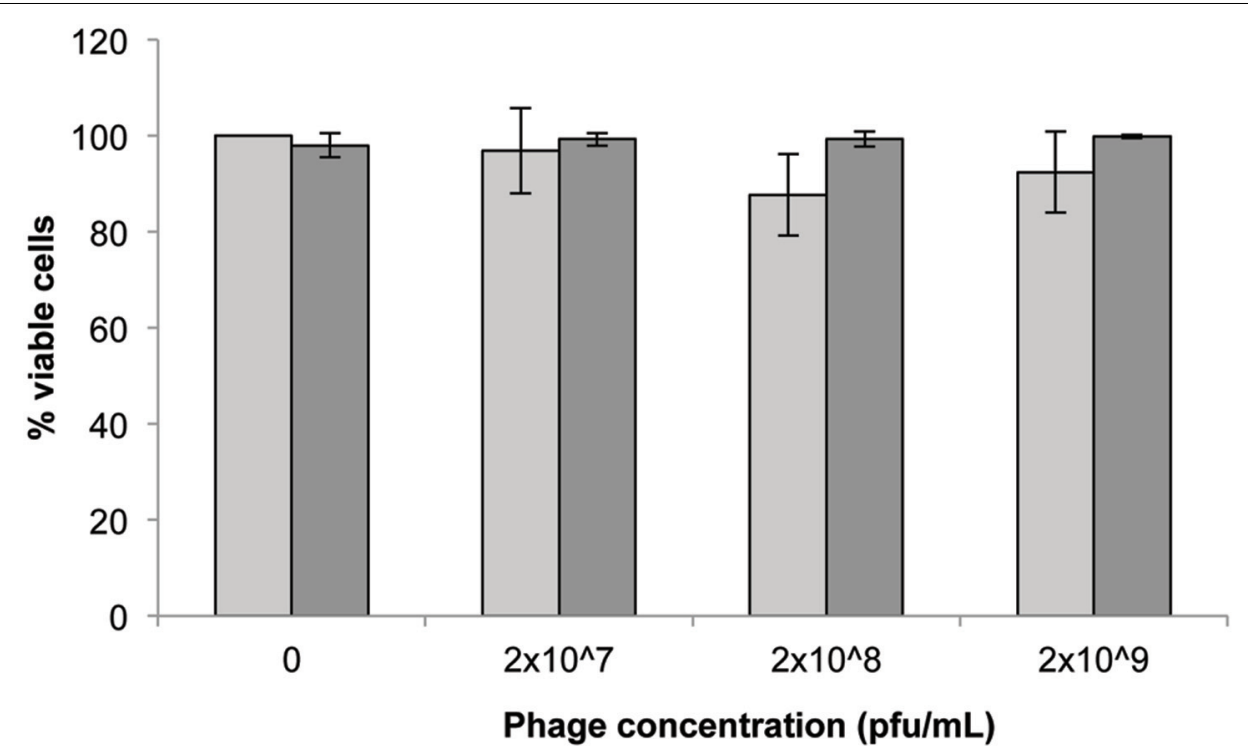

FIGURE 1 | 3T3 mouse fibroblast cell viability following $24 \mathrm{~h}$ exposure to Acinetobacter phage BS46 in DMEM by trypan blue exclusion assay. $5 \times 10^{3}$ cells/well; $\square: 2 \times 10^{5}$ cells/well. Data are the mean of 3 replicates \pm SD.

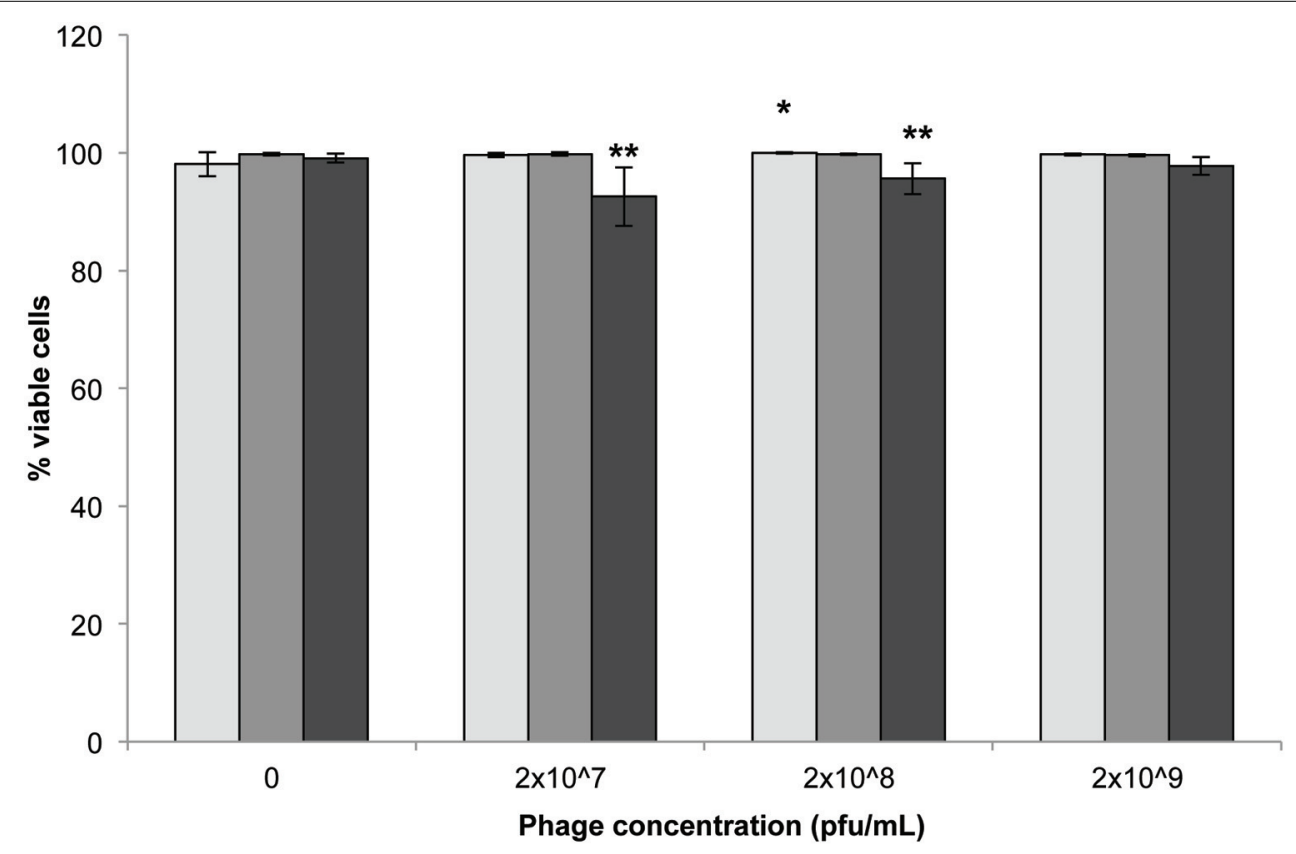

FIGURE 2 | 3T3 mouse fibroblast cell viability following exposure to Acinetobacter phage BS46 by Hoechst propidium iodide staining. : 24 , 口: 48 and $\mathbf{~} \mathbf{7 2} \mathbf{h}$. Data shown are the mean of 3 replicates $\pm \mathrm{SD}$. ${ }^{*} p<0.05$ compared to control, ${ }^{* *} p<0.001$ compared to controls and highest phage concentration $\left(2 \times 10^{9} \mathrm{pfu} / \mathrm{mL}\right)$ at $72 \mathrm{~h}$.

literature on the effects of the direct addition of therapeutic bacteriophages on immortalized cell lines such as 3T3 fibroblasts.

In the current investigation, a partially purified A. baumannii phage preparation was not cytotoxic to $3 \mathrm{~T} 3$ mouse fibroblast cell line, although some assay dependent differences in viability were observed. No statistically significant differences were seen between 3T3 cells treated with phage and untreated controls, corresponding with similar investigations performed by Merabishvili et al. (2009) against human neonatal foreskin keratinocytes when assessed by trypan blue exclusion. While patient derived cells will offer the closest analog to whole organism testing in vitro, the use of such cell types comes with associated cost and ethical considerations as well as increased variation between multiple donors. Although no substitute 


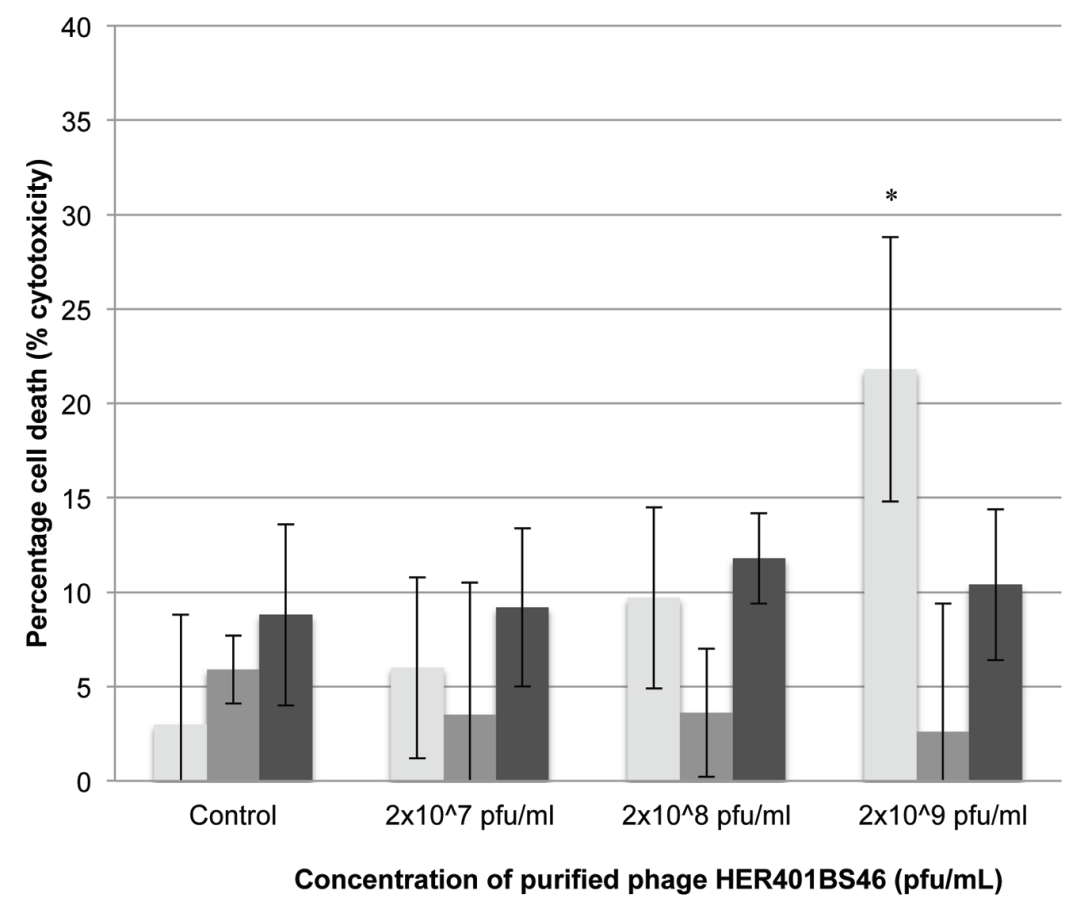

FIGURE 3 | LDH release of 3T3 mouse fibroblast cells following exposure to Acinetobacter phage BS46. ${ }^{*} p<0.001$ compared to the control. $\square: 24$, $\square$ : 48 , and $\mathbf{\square}: 72 \mathrm{~h}$. Data shown are the mean of 3 replicates \pm SD.

A

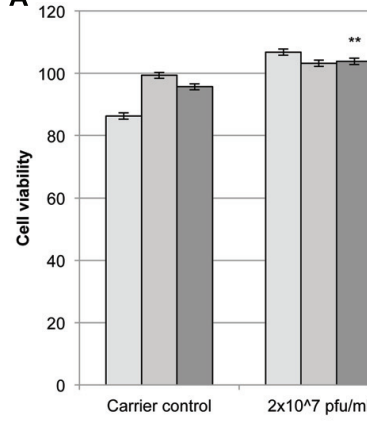

B

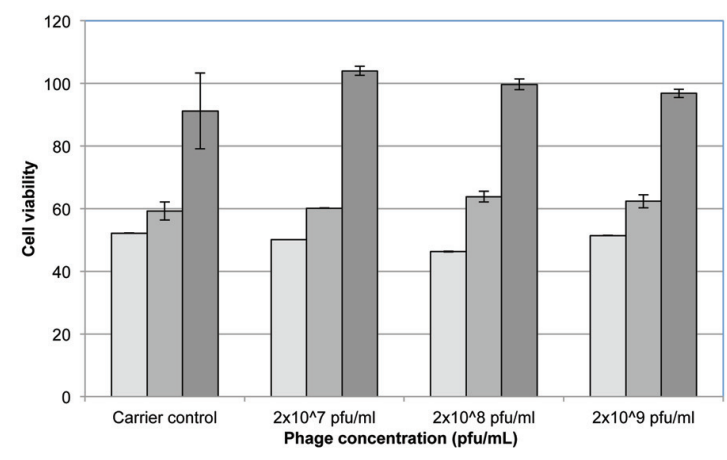

C
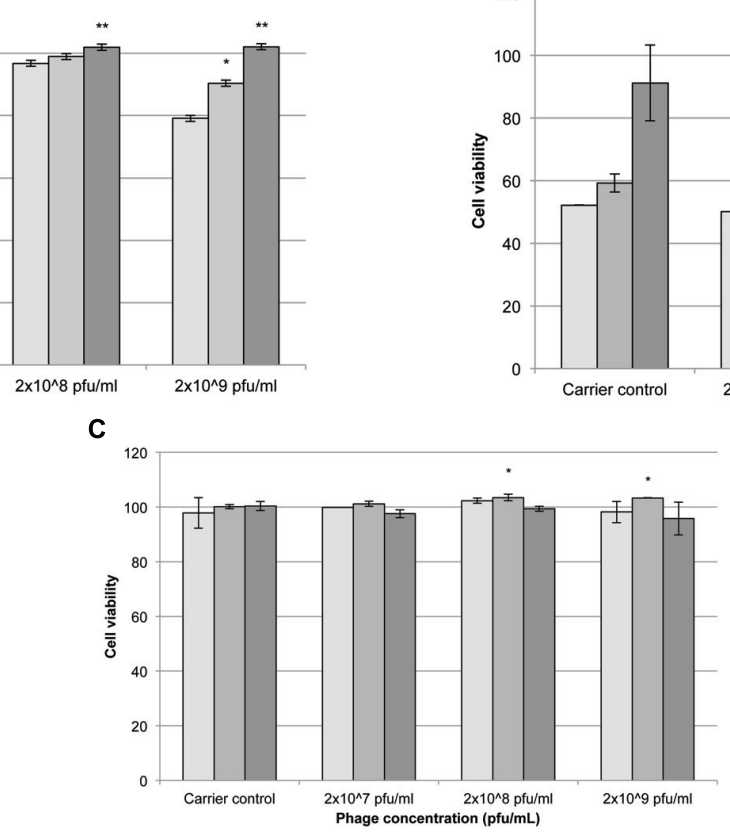

FIGURE 4 | The effect of Acinetobacter phage BS46 on MTS formation of 3T3 cells. Percentage cell viability was calculated from the untreated cells which represent 100\% viability. Carrier control corresponds to cells treated with $\lambda$ buffer. (A): $24 \mathrm{~h}$, (B): $48 \mathrm{~h}$, and (C): $72 \mathrm{~h}$ incubation. $\square 5000$ cells/well, $\square 10000$ cells/well and 15000 cells/well. ${ }^{*} p<0.05$, compared to $2 \times 10^{7} \mathrm{pfu} / \mathrm{mL} ;{ }^{*} p<0.05$ compared to $\lambda$ buffer. Data are the mean of 3 replicates \pm SD. 
for in vivo testing, the use of immortalized cell lines would decrease the overall research cost of preclinical studies and enable standardization between laboratories, allowing for better comparative testing to be performed. In addition fibroblasts were used in an attempt to understand the effect of phage on skin or wounds, recognizing that $A$. baumannii is an important wound pathogen.

Although no cytotoxic effect was observed with all the assays tested, the assessment of cellular viability with the MTS assay suggested that phages provided a positive effect on cell viability. This observation supports that of Chung et al. (2010) who reported that genetically engineered M13 bacteriophage improved cell attachment under specific experimental conditions. Although no direct cytotoxic effect was observed, the addition of phages has been shown to induce pro-inflammatory cytokines such as IL-10 and IFN$\gamma$ (Dąbrowska et al., 2014; Park et al., 2014). Majewska et al. (2015) reported a weak antibody production in mice following T4 phages ingestion. However, this is dependent on phage type and the protein composition of individual phages (Dąbrowska et al., 2014) and would be of particular importance in nontopical applications that would result in the increased exposure of phages to the immune system (Hodyra-Stefaniak et al., 2015). Here we have used a partially purified phage and it is possible that bacterial debris were present in the preparation. However, the phage preparation used here did not show any cytotoxicity overall. The endotoxin level of any phage product would need to be measured for regulatory purposes before commercialization. A number of methods to reduce endotoxin levels have been described: a single round of PEG precipitation and centrifugation has been shown to remove up to $88 \%$ of endotoxins from a bacteriophage preparation (Branston et al., 2015). However, additional purification stages such as ultracentrifugation in a $\mathrm{CsCl}$ gradient or chromatographic methods will further reduce impurities (Boratyński et al., 2004).

The current investigation sought to assess the cytotoxicity of a purified preparation of A. baumannii phage BS46 using four separate methods. Some discrepancies in the results were observed, notably at high phage concentrations, with the PI and MTS assay showing some small but statistically significant reduction in cell number and the $\mathrm{LDH}$ assay showing no significant differences in cell viability. The LDH assay presented

\section{REFERENCES}

Ackermann, H. W., Brochu, G., and Konjin, H. P. E. (1994). Classification of Acinetobacter phages. Arch. Virol. 135, 345-54. doi: 10.1007/BF01310019

Adams, M. (1959). Bacteriophages. New York, NY: Interscience Publishers.

Anonymous (2012). Scientific opinion on the evaluation of the safety and efficacy of listextm P100 for the removal of listeria monocytogenes surface contamination of raw fish. EFSA J. 10:2615.

Antunes, L. C., Visca, P., and Towner, K. J. (2014). Acinetobacter baumannii: evolution of a global pathogen. Pathog. Dis. 71, 292-301. doi: 10.1111/2049632 X.12125

Belloc, F., Dumain, P., Boisseau, M. R., Jalloustre, C., Reiffers, J., Bernard, P., et al. (1994). A flow cytometric method using Hoechst 33342 and propidium iodide for simultaneous cell cycle analysis and apoptosis determination in unfixed cells. Cytometry 17, 59-65. doi: 10.1002/cyto.990170108 the highest variability in results as indicated by the large error bars. It measures the activity of the oxidoreductase of $\mathrm{LDH}$, a stable enzyme, released from damaged cells in the culture medium. Variability in activity, which has been reported in other applications (Bopp and Lettieri, 2008), may be cause by differences in cell seeding. Such variability in results was not noted with the other assays performed. Both the Trypan blue exclusion assay and the Hoechst and PI assays require microscope based analysis which may limit their usefulness although high throughput protocol could potentially be increased using flow cytometry. The MTS assay gives indirect measurement of viability [requires metabolism of MTS (3-(4,5-dimethylthiazol-2-yl)-5-(3-carboxymethoxyphenyl)-2-(4sulfophenyl)-2H-tetrazolium] to formazan and not a measurement of cell damage. This indirect measurement based on cell metabolism may explain why the MTS assay was the only one that showed an increased in cell viability. For developing a product for phage therapy, for which a high number of samples need to be processed, the high throughput trypan blue assay may be the most practical protocol to use. It is thus important to consider the method used to assess the cytotoxic effects of phage preparations and highlights the pressing need for standardized phage testing protocols.

The purified phage suspension exhibited little toxicity and this result is encouraging for the treatment of topical infections with phages. For non-topical applications, the assessment of cytotoxicity could be complemented with the determination of immune-stimulatory capacity (Merabishvili et al., 2009; SzermerOlearnik and Boratyński, 2015).

\section{AUTHOR CONTRIBUTIONS}

Conceived and designed experiments: AH, GH, SD, J-YM. Performed experiments AH. Analyzed data: AH, GH, SD, J-YM. Wrote the manuscript: CC, J-YM, GH, SD.

\section{FUNDING}

This study resulted from a Ph.D. studentship funded by the University of Brighton and the Royal Pharmaceutical Society of Great Britain.

Biswas, B., Adhya, S., Washart, P., Paul, B., Trostel, A. N., Powell, B., et al. (2002). Bacteriophage therapy rescues mice bacteremic from a clinical isolate of vancomycin-resistant Enterococcus faecium. Infect. Immun. 70, 204-210. doi: 10.1128/IAI.70.1.204-210.2002

Boratyński, J., Syper, D., Weber-Dabrowska, B., Łusiak-Szelachowska, M., Poźniak, G., and Górski, A. (2004). Preparation of endotoxin-free bacteriophages. Cell. Mol. Biol. Lett. 9, 253-259.

Bopp, S. K., and Lettieri, L. (2008). Comparison of four different colorimetric and fluorometric cytotoxicity assays in a zebrafish liver cell line. BMC Pharmacol. 8:8. doi: 10.1186/1471-2210-8-8

Branston, S. D., Wright, J., and Keshavarz-Moore, E. (2015). A nonchromatographic method for the removal of endotoxins from bacteriophages. Biotechnol. Bioeng. 112, 1714-1719. doi: 10.1002/bit.25571

Bren, L. (2007). Bacteria-eating virus approved as food additive. FDA Consum. 41, 20-22. 
Cai, Y., Chai, D., Wang, R., Liang, B., and Bai, N. (2012). Colistin resistance of Acinetobacter baumannii: clinical reports, mechanisms and antimicrobial strategies. J. Antimicrob. Chemother. 67, 1607-1615. doi: 10.1093/jac/dks084

Carmichael, J., DeGraff, W. G., Gazdar, A. F., Minna, J. D., and Mitchell, J. B. (1987). Evaluation of a tetrazolium-based semiautomated colorimetric assay: assessment of radiosensitivity. Cancer Res. 47, 943-946.

Chung, W. J., Merzlyak, A., and Lee, S. W. (2010). Fabrication of engineered M13 bacteriophages into liquid crystalline films and fibers for directional growth and encapsulation of fibroblasts. Soft Matter 6, 4454-4459. doi: 10.1039/c0sm00199f

Dąbrowska, K., Miernikiewicz, P., Piotrowicz, A., Hodyra, K., Owczarek, B., Lecion, D., et al. (2014). Immunogenicity studies of proteins forming the T4 phage head surface. J. Virol. 88, 12551-12557. doi: 10.1128/JVI.02043-14

Fotakis, G., and Timbrell, J. A. (2006). In vitro cytotoxicity assays: comparison of $\mathrm{LDH}$, neutral red, MTT and protein assay in hepatoma cell lines following exposure to cadmium chloride. Toxicol. Lett. 160, 171-177. doi: 10.1016/j.toxlet.2005.07.001

Hanlon, G. W. (2007). Bacteriophages: an appraisal of their role in the treatment of bacterial infections. Int. J. Antimicrob. Agents 30, 118-128. doi: 10.1016/j.ijantimicag.2007.04.006

Hodyra-Stefaniak, K., Miernikiewicz, P., Drapała, J., Drab, M., JończykMatysiak, E., Lecion, D., et al. (2015). Mammalian host-versus-phage immune response determines phage fate in vivo. Sci. Rep. 5:14802. doi: $10.1038 /$ srep 14802

Kutter, E., De Vos, D., Gvasalia, G., Alavidze, Z., Gogokhia, L., Kuhl, S., et al. (2010). Phage therapy in clinical practice: treatment of human infections. Curr. Pharm. Biotechnol. 11, 69-86. doi: 10.2174/138920110790725401

Los, F. C., Randis, T. M., Aroian, R. V., and Ratner, A. J. (2013). Role of poreforming toxins in bacterial infectious diseases. Microbiol. Rev. 77, 173-207. doi: 10.1128/mmbr.00052-12

Majewska, J., Beta, W., Lecion, D., Hodyra-Stefaniak, K., Klopot, A., Kazmierczak, Z., et al. (2015). Oral application of T4 phage induces weak antibody production in the gut and in the blood. Viruses 7, 4783-4799. doi: 10.3390/v7082845

Merabishvili, M., Pirnay, J.-P., Verbeken, G., Chanishvili, N., Tediashvili, M., Lashkhi, N., et al. (2009). Quality-controlled small-scale production of a welldefined bacteriophage cocktail for use in human clinical trials. PLoS ONE 4:e4944. doi: 10.1371/journal.pone.0004944

Morello, E., Saussereau, E., Maura, D., Huerre, M., Touqui, L., and Debarbieux, L. (2011). Pulmonary bacteriophage therapy on Pseudomonas aeruginosa cystic fibrosis strains: first steps towards treatment and prevention. PLoS ONE 6:e16963. doi: 10.1371/journal.pone.0016963

Park, K., Cha, K. E., and Myung, H. (2014). Observation of inflammatory responses in mice orally fed with bacteriophage T7. J. Appl. Microbiol. 117, 627-633. doi: 10.1111/jam.12565

Perfetto, B., Donnarumma, G., Criscuolo, D., Paoletti, I., Grimaldi, E., Tufano, M. A., et al. (2003). Bacterial components induce cytokine and intercellular adhesion molecules-1 and activate transcription factors in dermal fibroblasts. Res. Microbiol. 154, 337-344. doi: 10.1016/S0923-2508(03) 00084-6

Qureshi, Z. A., Hittle, L. E., O’Hara, J. A., Rivera, J. I., Syed, A., Shields, R. K., et al. (2015). Colistin-resistant Acinetobacter baumannii: beyond carbapenem resistance. Clin. Infect. Dis. 60, 1295-1303. doi: 10.1093/cid/civ048

Rhoads, D. D., Wolcott, R. D., Kuskowski, M. A., Wolcott, B. M., Ward, L. S., and Sulakveldze, A. (2009). Bacteriophage therapy of venous leg ulcers in humans: results of a phase i safety trial. J. Wound Care 18, 237-243. doi: 10.12968/jowc.2009.18.6.42801

Soothill, J. S. (1992). Treatment of experimental infections of mice with bacteriophages. J. Med. Microbiol. 37, 258-261. doi: 10.1099/00222615-37-4258

Strober, W. (2001). Trypan blue exclusion test of cell viability. Curr. Prot. Immunol. 3(Suppl. 21), A.3B.1-A.3B.2. doi: 10.1002/0471142735.ima03bs21

Szermer-Olearnik, B., and Boratyński, J. (2015). Removal of endotoxins from bacteriophage preparations by extraction with organic solvents. PLoS ONE 10:e0122672. doi: 10.1371/journal.pone.0122672

Tang, Y., Sun, F., Li, X., Zhou, Y., Yin, S., and Zhou, X. (2011). Porphyromonas endodontalis lipopolysaccharides induce RANKL by mouse osteoblast in a way different from that of Escherichia coli lipopolysaccharide. J. Endod. 37, 1653-1658. doi: 10.1016/j.joen.2011.08.015

Tardif, F., Ross, G., and Rouabhia, M. (2004). Gingival and dermal fibroblasts produce interleukin-1 beta converting enzyme and interleukin-1 beta but not interleukin-18 even after stimulation with lipopolysaccharide. J. Cell. Physiol. 198, 125-132. doi: 10.1002/jcp.10400

Wright, A., Hawkins, C. H., Änggård, E. E., and Harper, D. R. (2009). A controlled clinical trial of a therapeutic bacteriophage preparation in chronic otitis due to antibiotic-resistant Pseudomonas aeruginosa; a preliminary report of efficacy. Clin. Otolaryngol. 34, 349-357. doi: 10.1111/j.1749-4486.2009. 01973.x

Zarrilli, R., Pournaras, S., Giannouli, M., and Tsakris, A. (2013). Global evolution of multidrug-resistant Acinetobacter baumannii clonal lineages. Int. J. Antimicrob. Agents 41, 11-19. doi: 10.1016/j.ijantimicag.2012.09.008

Conflict of Interest Statement: The authors declare that the research was conducted in the absence of any commercial or financial relationships that could be construed as a potential conflict of interest.

Copyright (c) 2016 Henein, Hanlon, Cooper, Denyer and Maillard. This is an openaccess article distributed under the terms of the Creative Commons Attribution License (CC BY). The use, distribution or reproduction in other forums is permitted, provided the original author(s) or licensor are credited and that the original publication in this journal is cited, in accordance with accepted academic practice. No use, distribution or reproduction is permitted which does not comply with these terms. 